\title{
Sisäistyneet ristiriidat, tunnetyö ja tietotyöläissubjektiviteetin rakentuminen
}

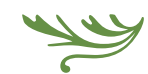

Yliopistotyö on esimerkki uuden työn muodoista, joissa työ kiinnittyy aiempaa vahvemmin yksilöön. Samalla vastuu työelämän vaatimuksiin yltämisestä siirtyy työntekijälle itselleen. Työyhteisön ristiriitatilanteissa organisaation ongelmat sisäistyvät työntekijän yksityisiksi ja tunne-elämän ongelmiksi.

SUOMALAINEN YLIOPISTOLAITOS ON jOutunut perustelemaan merkitystään ja tehtäväänsä yhteiskunnassa uusilla tavoilla. Vuodesta 1998 lähtien yliopistoissa on koettu lukuisia muutoksia. Näitä ovat siirtyminen kokonaistyöaikaan, valtion virkamieskoneiston voimakas supistaminen tuottavuusohjelman nimissä, "tehtävien vaativuuteen" perustuvan palkkausjärjestelmän käyttöönotto, työajan kohdennusjärjestelmät, neliportaiseen tutkijanuramalliin siirtyminen, tohtorin tutkintojen ja opiskelijoiden määrän lisääntyminen sekä yliopistojen yksityistäminen ja sen myötä alkaneet yksityisen rahan kerjuuoperaatiot. (Puhakka \& Rautopuro 2012, 28.) Yliopistotyö on nostettu pa- radigmaattiseksi esimerkiksi uuden työn muodoista, joissa työ on muuttunut yksilöön aiempaa vahvemmin kiinnittyväksi, yksilöä vahvemmin vastuullistavaksi sekä yksilöllisiä tunteita hyödyntäväksi (Raunig 2013).

Tarkastelemme artikkelissa, kuinka tietotyöläissubjektiviteetti - tässä tapauksessa yliopistotyöntekijä - rakentuu ja rakentaa itseään silloin, kun työyhteisön toiminnasta puuttuu riittävä ennustettavuus ja johdonmukaisuus. Kuvaamme haastatteluaineistosta erityisesti niitä tapoja, joilla tietotyöläinen problematisoi ja työstää itseään tilanteessa, jossa organisaation ongelmat sisäistyvät yksilön kokemusmaailman ja tunne-elämän ristiriidoiksi. 


\section{SUBJEKTIVOITUNUT JA AFFEKTIIVINEN TYÖ}

Työelämän muutoksista on kirjoitettu viimeisen vuosikymmenen aikana runsaasti. On puhuttu muutoksesta fordismista kohti postfordismia, aineellisesta tuotannosta kohti aineetonta tuotantoa, teollisesta työstä kohti jälkiteollista palvelutyötä ja niin edelleen (ks. esim. Vähämäki 2003; Hardt \& Negri 2005; Julkunen 2008; Jakonen 2015). Artikkelin kannalta merkittävimmät työssä ja työprosessin hallinnassa tapahtuneet muutokset voidaan tiivistää kahteen huomioon.

Työ on ensinnäkin - pitkälle teollistuneissa länsimaissa - subjektivoitunut. Se ei enää ole ihmisen persoonallisuudesta erillinen elämän osa-alue, vaan pikemminkin maasto, jossa ihmisen persoonallisuus ja subjektiviteetti rakentuvat. Työn subjektivoituminen viittaa myös siihen, että entistä useammassa työtehtävässä ihmisen persoonallisilla piirteillä, kyvyillä ja taidoilla on keskeinen merkitys. (Holvas \& Vähämäki 2005; Julkunen 2008.)

Persoonaan voimakkaasti kiinnittynyttä työtä on myös vaikea enää valvoa täysin ulkoisesti. Siitä huolimatta, että esimerkiksi työajan tarkka valvonta on edelleen osa monen työntekijän arkipäivää, subjektivoituneessa työssä kontrolli sisäistyy myös yksilöön itseensä erinäisin henkilökohtaisin motivoinnin ja vastuullistamisen keinoin. (Mäkinen 2013, 153.)

Subjektivoituneessa työssä rajat työn ja vapaaajan, sekä toisaalta yksilön kehollisuuden, psyykkisten ominaisuuksien, tunteiden ja hänen työkykynsä välillä hälvenevät ja sulautuvat toisiinsa. Työkykyä ylläpidetään myös vapaa-ajalla, esimerkiksi ruumiin muokkaamisen avulla. Kuten Vähämäki (2003) on esittänyt, ero työn ja (työn) tekijän välillä katoaa. Töihin joutuvat - etenkin palvelu-, opetus-, tutkimus- ja kulttuuriammateissa - ihmisen kaikki kyvyt ja yleiset taidot, ei vain rajattu ammattitaito. Työntekijä ei voi ainoastaan mekaanisesti suorittaa määrättyä tehtävää ja unohtaa niin tehdessä itseään, vaan hän joutuu panemaan peliin tunteensa, aistinsa ja lopulta koko elämänsä. Tässä suhteessa työ ei ole enää riippumaton tekijästään. (Ks. Julkunen 2008; Virtanen 2006.)

Edellä kuvatut muutokset vaikuttavat niin työprosessin hallintaan kuin yksilön suhtautumiseen työhönsä. Subjektivoituneessa työssä ulkoinen kont- rolli ei enää riitä, vaan työprosessin hallinnan ja organisoinnin on kolonisoitava työntekijän mielen elämä ja muututtava itseohjaukseksi ja -kontrolliksi (Rose 1989; Virtanen 2006, 250-257). Uudenlaiset tavat hallita omatoimisesti subjektivoitunutta työtä voivat tarkoittaa vapautta ulkoisista, tayloristiseen rationaliteettiin perustuvista objektivoivista hallinnan muodoista. Toisaalta niihin sisältyy uudenlaisia jännitteitä. Mikäli työssä on mukana yksilön koko persoona, eikä siis ainoastaan rajattu ammattitaito tai -kompetenssi, onnistuminen ja menestyminen vahvistavat persoonaa, kun taas epäonnistuminen näyttäytyy persoonallisuuden kriisinä (Julkunen 2008, 124; ks. myös Ehrenberg 2009). Esimerkiksi juuri työn kontrolli tai sen arviointi ei koske enää yksiselitteisesti itsen ulkopuolista suoritusta vaan koko persoonaa.

Subjektivoitunut työ kiinnittyy paitsi "persoonallisen” minän kultivointiin ja sisäistyneisiin kontrollin muotoihin, myös työn tunteisiin kytkeytyvien ja psyykkisten ulottuvuuksien korostamiseen. Tunteet ja ihmisen mielen elämä ovat aina olleet osa työprosessia, mutta nykyään eri tavoin ja intensiivisemmin kuin aiemmin. Siinä missä aiemmin tunteiden ei katsottu kuuluvan työpaikalle, nyt ne ovat olennainen osa työn arkea. Kyse ei kuitenkaan ole pelkästään "tunteiden sallimisesta” työelämässä, sillä subjektivoituneessa työssä tunteista muodostuu keskeinen osa-alue, jossa ihmiset sekä työstävät että kontrolloivat itseään. Onkin puhuttu työn affektiivisesta, tunteellisesta ja tunteita hyödyntävästä käänteestä. (Jokinen 2010; Jokinen \& Venäläinen 2015.)

Tunteita hyödyntävästä työstä on tullut yksi eniten lisäarvoa tuottavista, sekä yksi työn organisointia koskevista hallinnan muodosta (Hardt 1991). Keskeistä tässä muutoksessa on se, kuinka tunteet, affektit ja tunteellisuus nousevat työn ja arvonmuodostuksen piiriin sellaisenaan. Työnantajat vaativatkin rekrytoidessaan yhä useammin työntekijöiltä ominaisuuksia, kuten sopeutuvuutta, reaktiokykyä, sosiaalisuutta ja vuorovaikutustaitoja (Jokinen 2010, 46). Samanaikaisesti kun tunteista ja persoonallisuudesta voidaan tuottaa yhä enemmän lisäarvoa, kohdistuu myös työhön ja esimerkiksi työyhteisöön liittyvä problematiikka yhä voimakkaammin yksilön tunne-elämään (Dardot \& Laval 2014, 255-301; Rikala 2013). 
Edellä kuvatut työn muutosta koskevat yleiset huomiot kehystävät nykyaikaisen tietotyön empiiristä analyysia, joka on tämän artikkelin merkittävä kontribuutio. Työn muutokset subjektivoituneeksi ja affektiiviseksi auttavat hahmottamaan jännitteitä, joita tietotyöläisten yksilölliset, artikkelissa tapausesimerkkeinä toimivat kokemukset ilmentävät.

Teoreettista ja käsitteellistä keskustelua työn muutoksesta affektiiviseksi ja subjektivoituneeksi on käyty runsaasti viimeisen kymmenen vuoden aikana, mutta empiirisiä tutkimuksia aiheesta on niukalti. Käyttämämme aineisto on rajallinen siinä mielessä, ettei sen perusteella ole tarkoituskaan tehdä pitkälle meneviä yleistyksiä työn muuttuneesta luonteesta. Sen avulla voidaan kuitenkin tuoda työn muutoksia koskevaan keskusteluun vähälle huomiolle jäänyt, työntekijöiden kokemuksia jäsentävä empiirinen näkökulma.

\section{AINEISTO JA METODOLOGIA}

Artikkelimme käsittelee subjektiviteetin rakentumista tietotyössä. Aineistona käytämme seitsemää reilun tunnin mittaista nauhoitettua puolistrukturoitua yksilöhaastattelua. Ne on kerätty syksyllä 2013 yhden työyhteisön jäseniltä, jotka ilmaisivat kiinnostuksensa kertoa syrjässä olemisen kokemuksistaan työyhteisössä.

Haastattelut ovat osa laajempaa etnografista aineistoa, joka on kerätty havainnoimalla ja haastattelemalla yhdestä suurehkosta, pehmeään ja soveltavaan akateemiseen alaan (Ylijoki 1998) kuuluvasta yliopiston yksiköstä. Laajempi aineistonkeruu nojasi kysymyksiin: "Millaiset kokemukset organisaatiossa jäävät varjoon tai jopa pimentoon? Miksi joitakin kokemuksia on vaikeata kuunnella?” Aineistonkeruuvaihe sisälsi ennakko-oletuksen siitä, että työyhteisössä on jotakin sellaista, jonka merkityksiä ei tavoiteta arkisen olemisen tavoissa ja kielenkäytössä, jolla yhteisön elämää tavataan jäsentää.

Alustava, aineistolähtöinen (Eskola \& Suoranta 1998, 83) analyysi osoitti, että aineistoa olisi tarpeen jäsentää yksityisten kokemusten sekä yhteisöllisen ja yhteiskunnallisen merkityksen toisiinsa kietoutumisen näkökulmista.Tutkimuskysymyksiksi muotoutuivat:

1. Miten työntekijä rakentuu ja rakentaa itseään sopeuttamalla persoonansa nykyaikaisen tietotyön vaatimuksiin?
2. Millaisia muotoja sopeutuminen saa työntekijän kokemuksissa?

3. Millaisin tekniikoin ja järkeilyn tavoin työntekijä muokkaa tai vastustaa itseään, ruumistaan ja kokemusmaailmaansa suhteessa työlleen asetetuille tavoitteille ja vaatimuksille?

Jäsennämme haastatteluaineistosta yksilöllisten kokemusten ja yhteiskunnallisten merkitysten jännitteitä Michel Foucault'n subjektiviteetin rakentumista koskevien huomioiden avulla. Foucault oli kiinnostunut erityisesti siitä, kuinka yksilöt muokkaavat itseään suhteessa heille asetettuihin odotuksiin, "moraalilakeihin". Subjekti ei merkitse Foucault'lle pysyvää ja universaalia itseyttä, vaan historiallista muotoa, joka konkretisoituu niinä suhteina, joita yksilöt rakentavat itseensä. Foucault'n mukaan tällaiset itsekäytännöt rakentavat subjektien refleksiivisyyden muodon: ne ohjaavat sitä tapaa, jolla ihmiset ajattelevat itseään. (Foucault 1982; Alhanen 2007, 157.)

Minätekniikoilla, joiden analysoimiseen artikkelissa keskitymme, Foucault (1998) viittaa muotoihin, tekniikoihin ja artikulaatioihin, joiden avulla suhdetta itseen pyritään muodostamaan ja kehittämään. Minätekniikat kuvaavat sitä, kuinka subjektiviteetti rakentuu ja rakentaa itseään tietyssä historiallisessa muodostelmassa, kuten esimerkiksi subjektivoituneessa ja affektiivisessa työssä. Minätekniikoilla on neljä ulottuvuutta, joiden avulla analysoimme tietotyöläissubjektiviteetin rakentumista työyhteisöön liittyvissä ristiriitatilanteissa.

Suuntaamme ensin huomion niihin osa-alueisiin, jotka yksilö asettaa itsessään problemaattisiksi organisatorisissa ristiriitatilanteissa, ja joista näin tulee hallinnan ja työstämisen alaisia. Tätä aluetta Foucault itse kutsuu "eettiseksi substanssiksi”. Kuvaamme erityisesti sitä, mitä osa-alueita haastateltavat problematisoivat itsessään tilanteessa, jossa työyhteisön ongelmat sisäistyvät yksilön sisäisiksi ristiriidoiksi.

Seuraavaksi tarkastelemme, kuinka haastateltavat suhteuttavat itsensä problematisoituihin osa-alueisiin. Tätä ulottuvuutta Foucault kutsuu "alistumisen muodoksi”.

Kolmanneksi kuvaamme niitä tekniikoita, joilla haastateltavat työstävät itseään organisatorisissa ris- 
tiriitatilanteissa: kuinka he pyrkivät konkreettisesti mukauttamaan itsensä tai vastustamaan heissä itsessään problematisoituja osa-alueita.

Lopuksi tarkastelemme mikä on se olemisen tapa - Foucault'n käsittein telos - johon edellä kuvaamamme minätekniikat lopulta pyrkivät, sekä kuinka ne suhteutuvat subjektivoituneen ja affektiivisen työn jännitteisiin. (Foucault 1998, 133-134.)

\section{ITSEN ARVOKKUUS JA KOKEMUSTEN PROBLEMATISOINTI}

Haastatteluissa keskeisenä vaatimuksena (tieto)työssä menestymiselle erottuu työntekijän persoonan taloudellinen arvokkuus ja hyödynnettävyys organisaatiolle. Haastateltavien kuvauksissa tämä ilmenee vaatimuksina ja odotuksina yrittäjämäiseen ja tuottavaan toimintaan. Nämä näyttäytyvät toisaalta muodollisesti itsestään selvinä tavoitteina, mutta jäävät samanaikaisesti sisällöllisesti tarkemmin määrittelemättömiksi. Näin työstä selviytyminen - tuottavan työn etsiminen ja valikointi - jää yrittäjämäisen tietotyöläisen vastuulle.

Eri ammattinimikkeitä edustavat haastateltavat määrittelevät kukin asemansa "hierarkiassa alimmaksi”. Vähäarvoisuuden kokemus on laajasti jaettu ja odotus etenemisestä työyhteisössä itseä kehittämällä näyttää olevan itsestään selvä oletus. Omaa arvoa yhteisölle ja yhteisössä mitataan jatkuvasti kysymyksellä, voisinko olla vielä arvokkaampi. Haastateltavat viittaavat useasti ulkoa määriteltyjen tulostavoitteiden, esimerkiksi "arvokkaan tutkimuksen tuottamisen” ja "kansainvälisyyden”, vaatimuksiin. Itseään on hillittävä keskittymällä mieluummin "tuottavaan” kuin "kiinnostavaan” tai "mielekkääseen” tekemiseen.

"[--] pitää koko ajan tasapainoilla sitte, koska mun päätyö on kuitenki tää akateemisen artikkeliautomaatin tehtävä, elikkä tuottaa niitä mahollisimman korkeen tason artikkeleita, joista sitte laitos hyötyy. Niin se sit aiheuttaa vähän ristiriitaa, että pitää niinku koko ajan hillitä itteensä ja mennä jarrut pohjassa ja yrittää vaan keskittyä siihen kirjottamiseen." (Haastattelu 2)

Itsensä hillitseminen kuvaa osuvasti sitä, kuinka työyhteisön problematiikka kääntyy yksilöön kohdis- tuvaksi problematisoinniksi. Hillitseminen voidaan tulkita siten, että työntekijän tulee itse ratkaista se, mikä on hyväksi työnantajalle, mutta myös se, mikä on loppujen lopuksi hyväksi hänelle itselleen. Näin työyhteisön ristiriidat eivät ole itsestään selvästi niinkään työyhteisön ja yksilön välillä, vaan pikemminkin molempien sisällä.

Kokemusten ilmaisu on keskeinen osa-alue, jonka haastatellut problematisoivat itsestään. Tämä tapahtuu siten, että osa kokemuksista koetaan sopimattomiksi itsen arvokkuuden vaatimuksen näkökulmasta.

"Meillä ei venettä saa keikuttaa, eikä oikein asioista saa puhua. Ellet halua olla ikävä ihminen. Ja sit se estää mun mielestä paljon kehitystä." (H4)

Problematisoidut kokemukset liittyvät haastatteluissa varsin usein epätasa-arvoiseen kohteluun työsuhteen ehtojen, palkkauksen ja työn organisoinnin suhteen. Näitä epäkohtia ei koeta mahdolliseksi organisaatiossa käsitellä eikä edes tuntea, vaan arvokkuuden säilyttämiseksi yksilön on säädeltävä tarkasti ilmaisuaan.

"Ja mä oon niinku johonki suuntaan viestinytkii tästä, niinku alistavista käytänteistä, mut silti käydään kaikki yt:t ja kaikennäköset palkkaneuvottelut, joista ei niinku yhtään mitään voi mihinkään liikuttaa. [--] nää on vaikeita asioita johtaa ja ihmiset on herkistyny eri tavalla, mut niinku puheenparsi tuolla johtohenkilöstössä niin usein on semmosia hirveen niinku, ehkä tahtomattaan syyllistäviä, että pitäis kuitenki pystyä niinku tsemppaamaan satasella tähän niinku. [--] Tää ihmisen holistinen, henkinen, tää ihminen joka [naurahdus] tarvitsee turvaa ja toimeentuloa, nii sitä ei haluta niinku mitenkään tunnistaa." (H4)

Työn tekemiseen ja työyhteisössä olemiseen sisältyy siis piirteitä, joiden koetaan estävän tai ainakin hankaloittavan yksilön arvokkuuden kokemuksia yhteisössä. Näin yksilön kokemusmaailma ja tunne-elämä sekä niiden hallinta muuttuvat haastattelujen valossa eettiseksi substanssiksi, jonka haastateltavat asettavat muokattavaksi itsestään. Muokkauksen alle joutuu erityisesti "vääränlaisten” kokemusten pidättely. Kun työyhteisössä ilmenee ristiriitoja, niitä hoidetaan läh- 
tökohtaisesti ihmissuhdeongelmina. Ristiriitatilanteissa työntekijöitä ohjataan muun muassa kursseille, työvalmennukseen ja työpaikkapsykologille.

"Meil oli tämmönen, mut se oli aivan jotenkin ufo tilanne se, että se tota työpaikkapsykologi piti meille siis luennon niinku aktiivisista tämmösistä alaistaidoista, ja se oli luento." (H1)

Yrittäjämäiseen ja yksilölliseen tuottavuuteen kohdistuvat vaatimukset sekä kokemusten pidättäminen näyttävät johtavan yksilön kannalta irrallaan olemisen kokemukseen. Koska kokemuksiin liittyviä tunteita ei voida sellaisenaan sisällyttää työhön, koetaan ne mahdolliseksi ottaa käyttöön vain hierarkiassa etenemisen ja tuottavuuden vaatimuksia mukailevin osin.

\section{ITSEN ALISTAMINEN JA VAATIMUSTEN PROBLEMATISOINTI}

Asettaessaan itsensä arvokkuuden ja tuottavuuden substansseihin haastateltavat sopeutuvat organisaation päämärïin alistamalla itsensä ja omat tavoitteensa niille. Organisaation päämäärät näyttäytyvät kuitenkin epämääräisinä ja ristiriitaisina yksilön kannalta. Yksilön on esimerkiksi rajoitettava omaa työtään ja omia mielenkiinnon kohteitaan saavuttaakseen toivomansa aseman työyhteisössä.

Haastateltavat kuvaavat tätä “ajautumisen” kokemuksina, joissa yksilö ikään kuin löytää itsensä tilanteesta, jota hän ei ole joko ajatellut hoitavansa, tai jonka hoitaminen ei lähtökohtaisesti kuulu hänen toimenkuvaansa. Kun "kukaan muu ei tee sitä hommaa”, avautuu hierarkiassa alempana oleville ainakin näennäinen mahdollisuus asemiin, joihin he eivät yleensä koe pääsevänsä. Tilanne herättää työntekijässä toiveita saavuttaa yhteisössä “tärkeä” asema. Samaan aikaan hän kuitenkin tiedostaa, ettei kyseessä ole todellinen "luottamuksenosoitus", vaan tilanne jolle ei löydy hoitajaa.

"[--] mun asema on tärkeä, koska kukaan muu ei tee sitä hommaa. Mutta se ei oo niinku tärkeä sen takia, että mulle ois jotenkin niinku annettu sillai jotenki, et se ei oo niinku luottamuksenosoitus että nyt minulle on annettu tällanen asia, vaan se vaan on että ku siinä ei oo ketään muuta." (H3)
Alistumisissa on oleellista yksilön tai pienen, keskenään tasa-arvoisen ryhmän, kuten hierarkiassa matalalla olevat, vastuullistaminen. Alistumisen mekanismi on se, että työntekijässä herää ajatus, että vastuun kantaminen on hänen omienkin etujensa mukaista ja että tehtävästä täytyy selviytyä itse ilman apua tai tukea.

Itsen alistaminen organisaation ristiriitaisilta vaikuttaviin vaatimuksiin näyttää liittyvän huoleen itsestä ja oman suorituskyvyn rajallisuudesta. Itsen arvokkuuteen ja tuottavuuden odotuksiin sisältyvät vaatimukset eivät rajoitu ainoastaan varsinaiseen työntekoon, vaan myös esimerkiksi yksilön kehoon ja mielen elämään. Haastateltavat kuvaavat tätä huolena yhtäältä siitä "miten saa niinku mahollisimman tehokkaasti irti sitte kirjotusta ja tulosta, kun ei aina ole suinkaan parhaimmillaan" (H2), sekä toisaalta huolena omasta tulevaisuudestaan ja paikastaan yhteisössä:

"Mutta kyllähän mä oon työnohjausryhmässä tällä hetkellä, niin kylhän tää tähän omaan tulevaisuuteen liittyvät kysymykset, nyt se mulle palaa vasta, niin meit on hyvin erilaisia ihmisiä, niin kyllä se sieltä nousee. Huoli eri tavalla auki puhuttuna, huoli tulevaisuudesta, ihmettely siitä omasta paikasta." (H4)

Pitäkseen yllä itsen arvokkuutta työntekijät alistavat itsensä myös sopeutumalla elämään ristiriitaisten ja usein yksilölle jopa sietämättömien tunteiden kanssa. Nämä tuntemukset jäävät myös kunkin yksityisiksi kokemuksiksi, mikä osaltaan edelleen vahvistaa yksilön irrallisuuden ja välineellisyyden kokemuksia.

"[--] semmost vastaantulemista ei tule. Semmosta, että tulis niinku kuullukstulemisen kokemus tai nähdykstulemisen kokemus tai sellanen niinku, että, et et niinku et okei tos on niinku uus ihminen ja otetaan se huomioon. Sä voit mennä tonne liittyy tai tonne liittyy, mut sä oot silti vähän niinku irti." (H1)

Kun koettu todellisuus ei ole jaettavissa, ristiriidat sisäistyvät yhä selkeämmin yksityisiksi ongelmiksi, joiden laajempia yhteyksiä ei tunnisteta. Ratkaisut on löydettävä "omin voimin” ja ongelmiin voi vaikuttaa vain itseään muuttamalla. Tällaisessa tilanteessa työntekijälle muodostuu kaksi tapaa suhtautua sietämättömiin tunteisiin: ongelmat voi sijoittaa itseensä 
tai lähityöyhteisöön ja käsitellä siellä tai vaihtoehtoisesti siirtää ne itsensä ulkopuolelle ja unohtaa.

On tavallista, että ongelmalliseksi asetetaan pieni lähityöyhteisö ja sen henkilösuhteet, ja tunnepitoiset taistelut käydään lähipiirissä. Eräs haastateltava kuvaa lähityöyhteisössä tapahtuneiden henkilöstövähennysten jälkeen kärjistyneitä henkilösuhteita näin:

"[--] meitä käytettiin työpaikkapsykologin juttusilla ja oli johtajan kanssa palaveria ja kaikkee, et että se, se tota, niinku sillälailla laajeni ja se taas aiheutti semmost, et meillä [lähityöyhteisössä] sellanen pelko lisäänty. [-] Sit siinä tuli jo tämmösiä persoonallisuushäiriöepäilyjä ja muita niinku tähän liittyen ja sit tavallaan niinku johdolle selvis tää kuvio ja se niinku helpotti tai toi semmosta turvallisempaa oloo meidän [lähityöyhteisöön], mut meillon edelleen semmonen tilanne, et väki on hyvin eristäytynyttä ja." (H1)

Edellä kuvatussa tapahtumassa syyksi epäillään kiusaajaksi koetun työntekijän omia ongelmia ja henkilöhistoriaa. Näin ollen työyhteisön vaikea tilanne, johon on liittynyt myös työvoiman vähennys, on kilpistynyt työyhteisöön jääneiden ihmisten väliseksi ongelmaksi ja jopa epäilyksi yksittäisen henkilön patologiasta.

Nämä itsen alistamisen muodot eristävät tapahtumien koko organisaatiota koskettavan sekä pohjimmiltaan yhteiskunnallisen luonteen pois asian käsittelystä. Ristiriidat ovat sisäistyneet yksilön tai pienen ryhmän ongelmaksi, ja organisaation kannalta ne voidaan katsoa "ratkaistuiksi", koska kyse on ongelmallisista persoonista ja henkilösuhteista. Huolimatta siitä, millaisia ongelmat ovat laadultaan ja mistä ne ovat peräisin, oleellista on, että laajempaa selitysmallia ei edes harkita käsiteltäväksi. Näin itsen alistamisen mekanismit toimivat autonomiseksi mielletyn yrittäjämäisen minän kautta, joka pahimmillaan jää sekä ristiriitatilanteiden selvittäjäksi että niiden alkuperäiseksi syyksi.

Organisaation ristiriitaiset vaatimukset tuottavat myös vastustusta. Passiivinen vastarinta, esimerkiksi omissa oloissaan pysytteleminen, esiintyy haastatteluissa keinona taistella vaatimuksia vastaan. Eräs haastateltava kertoo ottaneensa tietoisesti ja omasta halustaan etäisyyttä työyhteisön työryhmiin, koska niissä ei voi vaikuttaa eikä työaika riitä niihin osallistumiseen. Enimmäkseen haastateltavien ajatukset vaatimusten vastustamisesta ovat kuitenkin varsin hypoteettisia pohdintoja mahdollisuudesta pysytellä organisaatiossa "näkymättömänä" ja näin jatkuvien vaatimusten saavuttamattomissa:

\section{"Ehkä näkymättömyys antaa vapautta toimia." (H7)}

Vaikka jotkut haastateltavat hahmottavat tilanteensa mahdottomuuden, ei toimintamahdollisuuksia juuri ole näköpiirissä. Työntekijän rooliksi koetaan jäävän joko ottaa tarjottu sopimus sellaisenaan vastaan tai olla ottamatta. Suorasanaisesti rakenteita kritisoivat tai jopa niitä vastaan nousevat haastateltavat ovat poikkeustapauksia. Tällöin koetut epäkohdat nostetaan aktiivisesti esille.

"Tää koko hallintokuvio on se, joka särkee yhteisöllisyyden. Se toimii juuri ristikkäin, yhteisöllisyyttä vastaan. (H6)

Työn organisoinnin kysymyksiä avoimesti problematisoiva työntekijä jää kuitenkin yksin, kun hallinto väistää kysymykset, eikä siihen saa kontaktia, esimerkiksi epäselviin kysymyksiin yksiselitteistä vastausta. Myös työkaverit jättävät "purnaajan” tiukan paikan tullen yksin. Koko työyhteisö osallistuu tämän järjestyksen ylläpitämiseen. Tilannetta pitää osaltaan yllä hierarkiassa ylempänä olevien kollegojen "hyväntahtoinen” kehuskelu ja lohduttelu.

"Onko sitte ehkä semmosena pienenä lisätarkennuksena, että myöskään sitte että ei ainoastaan niinku johto vaikene tästä et täs on kahden kerroksen väkeä, pätkäläiset ja pysyvät, vaan sit myöski työkaverit. Nää voi olla hyvin vaikeita asioita käsitellä inhimillisesti [--]" (H4)

"Mä sanoin että eihän tää [erään työn organisointi] oo ollenkaan niinku järkevää. [Professorin nimi] kyllä lohdutti, että no sä vastaat yksin niitä kaikkia, mutta [naurahdus], et se oli ihan kauniisti sanottu, mutta tota, mut et kuitenki niin mä koin niinku sillai." (H5)

Myötätunto esitetään henkilökohtaisesti, mikä viittaa siihen, että ongelmat ja niiden ratkaisumahdollisuudet nähdään henkilökohtaisina, yksilöön kiinnittyneinä. 


\section{ODOTUSTILA, ITSEN MUOKKAAMINEN JA TUNNETYÖ}

Haastatteluissa työntekijät kuvaavat erilaisia toimintoja ja tekniikoita, jotka voidaan tulkita yrityksiksi vastata arvokkuuden ja yrittäjämäisyyden vaatimuksiin. Eräs näistä on asettuminen odotustilaan, jossa itsensä alistamista organisaation epäselviin tai ristiriitaisiin tavoitteisiin työstetään välttelemällä vääränlaista aktiivisuutta. Odotus on, että esimerkiksi ylimääräisten työtehtävien hoitaminen palkitaan lopulta ja näin yksilöstä tulee työyhteisön silmissä arvokas työntekijä. Itsen arvokkuutta työstetään odotustilassa ymmärtämisen, varovaisuuden ja hienovaraisuuden tekniikoin.

"[--] mä samanaikaisesti ymmärrän hyvin, et johtajan tehtävä on haastava [naurahtaa] niinku silleen, että. Et että tota, en haluu niinkun, en haluu myöskään olla meiän johtoo teilaamassa. Ja ymmärrän, et on hyviä ja huonoja päiviä [--]" (H1)

Huoli itsestä, oman suorituskyvyn rajallisuudesta sekä itsen arvokkuudesta hahmottuvat muun muassa siten, että yksilö pyrkii pitämään yllä tarvittavaa työkompetenssiaan esimerkiksi urheiluharrastuksen avulla. Nämä tekniikat eivät sellaisenaan liity työntekijän varsinaiseen työtehtävään, mutta niiden työstäminen on tärkeää itsen arvokkuuden ja oman paikkansa säilyttämiseksi työyhteisössä:

"[--] mä oon niin jotenkin onnellinen nyt, kun mä voin sanoo, että mulla on tänään rentoutusryhmä tai mullon tänään, mä meen joogaan, niin mullon ihan semmonen eri fiilis, että hei mä ihan eri tavalla niinkun voin olla semmonen täysvaltanen jäsen tässä porukassa." (H2)

Esimerkki kuvaa hyvin sitä, kuinka työ, työhön sisältyvien kompetenssien ylläpitäminen sekä toisaalta “täysivaltainen jäsenyys yhteisössä” leviävät varsinaisen työn piiristä myös yksilön vapaa-aikaan ja sellaiseen itsen työstämiseen, jolla ei muodollisesti ole roolia yksilön virallisessa työtehtävässä. Itsensä ja oman kehonsa työstäminen muodostuu tärkeäksi yksilölle tässä hetkessä menestymisen kannalta, mutta myös tulevaisuuden turvaamiseksi. Haastatteluissa tämä ilmenee muun muassa pyrkimyksenä löytää kei- noja itsen arvokkuuden säilyttämiseksi, sekä toisaalta siten, että yksilö yrittää ennakoida esimerkiksi joogaamisen olevan "pitkällä tähtäimellä hyväksi".

Toinen tapa pitää yllä itsen arvokkuutta on tunnetyö. Työntekijä työstää vaikeita tunteita itsessään tai lähityöyhteisössä. Oleellista on, että työstäminen tapahtuu rajatussa piirissä. Työnantaja esimerkiksi ohjaa käsittelemään tunteita työpaikkapsykologin vastaanotolla tai kuuntelemaan luentoa "aktiivisista alaistaidoista”. Mikäli tällaisia psyykkisiä palveluja ei ole, jäävät tunteet "omin voimin" selvitettäviksi yksityisiksi ongelmiksi. Kun työntekijä tulkitsee, että koetut ongelmat ovat "omalla vastuulla" ja että ne olisi syytä käsitellä yksityisinä tai lähityöyhteisössä, isoihinkaan ongelmiin ei oteta kantaa koko yhteisön tasolla.

Työntekijät kuvaavat tunnetyötä esimerkiksi tilanteissa, joissa ristiriidan syynä ovat työn ehdot ja palkkaus. Esimerkiksi tahtomattaan osa-aikaiseksi joutunut työntekijä huomaa joutuvansa opettamaan kolminkertaisen määrään kollegoihin verrattuna saadakseen heidän kanssaan saman palkan. Hän pyrkii ratkaisemaan ristiriitatilanteen asian "torjumisella", sen "sivuun työntämisellä" ja yrityksellä "olla ajattelematta tilannetta."

"Se on asia, jonka mä joudun mun tietosuudesta ikäänkuin torjumaan. Et mä työnnän sen sivuun, mä teen tällä hetkel kahekstast neljään tääl töitä ja mä työnnän sivuun sen, että mulla ropsahtaa se [osa-aikaisen työntekijän palkka] kuussa. Et yritän olla sitä niinku aattelematta." (H1)

Eräänlaiseksi vastapariksi yllä kuvatuille itseen suuntautuville torjunnan ja kieltämisen tekniikoille nousevat tavat ulkoistaa vaikeat tunteet itsensä ulkopuolelle. Aineistosta löytyy esimerkkejä, joissa työntekijä sijoittaa ongelmat itsensä ulkopuolelle, analysoimalla muita työyhteisön jäseniä. Ulkoistamalla itsensä hankalista ihmissuhteista voi katsella ongelmia ilman että kokee olevansa itse niihin osallinen.

"Mä enemmän ehkä noukin ja tiedostan sieltä niitä ihmisten välisiä suhteita, ja jotaki tunnistan esimerkiksi meidän työyhteisössä, että ai no tuohan on ihan selvä, aivan tyypillinen tapaus. Että sillä lailla pystyy ittensä ulkoistamaan, että näkee sen keissin siellä niin selvästi." (H6) 
Erityinen tekniikka ulkoistaa ristiriitaisia tunteita itsensä ulkopuolelle on ironia ja välineellisyyden kokemuksen reflektointi. Haastatteluissa nousee erityisesti esille pyrkimys oman välineellisyyden, mutta samalla myös siihen liittyvän voimattomuuden järkiperäistämiseen. Itsen arvokkuuteen sisältyvä välineellisyyden kokemus tiedostetaan, mutta samanaikaisesti se pyritään ulkoistamaan itsestä saattamalla organisaation toiminta isossa mittakaavassa "ymmärrettäväksi”:

"[--] meil ei oteta, työnantaja ei ota sellasta vastuuta meistä pätkätyöntekijöistä, ja se nyt, jos nyt vähän kyynisesti sanoo, nii se on ihan ymmärrettävää, ja mitään väliäkään [--]" (H4)

Organisaation toiminta, joka näyttäytyy yksilölle epäoikeudenmukaisena ja johon tuntuu mahdottomalta vaikuttaa, älyllistetään tekemällä se ymmärrettäväksi. Samalla muuttuu myös yksilön tapa puhua ja mieltää itseään. Tällaisessa tilanteessa työntekijä hylkää roolinsa kokijana, jolla on tunteet, joita organisaatiossa loukataan. Hän alkaa katsoa ja kuvata itseään ikään kuin sivusta osana esitystä, joka etenee vääjäämättömästi kohti epämiellyttäviä tuloksia.

\section{RISTIRIITOJEN SISÄISTYMINEN}

Olemme aineiston avulla kuvanneet yliopistotyöntekijöiden kokemuksia työyhteisössään. Analyysi piirtää kuvan emotionaalisista tilanteista, jotka muodostuvat yhteiskunnassa ja työelämän käytännöissä vallitsevien reunaehtojen pohjalta, mutta jotka tulkitaan työyhteisössä lähtökohtaisesti henkilökohtaisiksi ja tunne-elämän ongelmiksi.

Samoja jännitteitä on käsitelty laajemminkin työn tutkimuksessa. Esimerkiksi Mäkinen (2012) on tarkastellut, kuinka työelämävalmennuksessa subjektivoitunut työ pyrkii hyödyntämään yksilöllistä potentiaalia, joka yhtäältä näyttäytyy loputtomana joustavuutena ja toisaalta yksilöllisiä voimavaroja hyödyntävänä. Niin kutsutun prekarisaatio-teoriaperinteen piirissä on taas teoreettisemmin tarkasteltu, kuinka työn ja ihmisen persoonallisten piirteiden sekä heidän kokemusmaailmansa sekoittuminen toisiinsa muuttaa työn sekä perinteisten työtä ohjaavien organisaatioiden, kuten yliopistojen, luonnetta (Jakonen ym. 2006). Jokisen ja Venäläisen (2015) toimittamassa Prekarisaatio ja affekti -teoksessa on puolestaan käsitelty yksilöllisten kokemusten ja tunnesävyjen kautta niitä keinoja, joilla ihmiset tekevät elämästään “elettävää” jatkuvan epävarmuuden keskellä.

Artikkelissa analysoimamme työyhteisö kuvaa tapausesimerkkinä edellä mainittuja subjektivoituneeseen ja affektiiviseen työhön liittyviä jännitteitä. Aineiston useat esimerkit havainnollistavat osuvasti subjektivoituneeseen työhön liittyvää vapauden kaksoissidosta (Vähämäki 2015; ks. myös Onnismaa 2007). (Yliopisto)työhön sisältyy odotus vapaudesta, joka näyttäytyy rajattomana mahdollisuutena edistyä urallaan ja "kivuta” organisaatiossa ylöspäin. Toisaalta tämä vapaus on tarkasti rajattua ja määräytyy loppujen lopuksi organisaation johdosta käsin. Näin työhön liittyvä vapaus pitää sisällään velvoittavia ja itsen vastuullistamiseen liittyviä pyrkimyksiä. Vapaus ei ole esimerkiksi kykyä arvioida kriittisesti ja ottaa etäisyyttä organisaation kaikille yhteisiksi esittämiin vaatimuksiin tai välttämättä edes kykyä tehdä itselleen mielekkäitä ja tärkeitä asioita, vaan pikemminkin velvollisuutta kehittää ja ylläpitää työkykyään organisaation esittämien vaatimusten mukaisesti.

Erääksi teemaksi aineistossa muodostuu elämän ja työn yhteensulautuminen (ks. myös Virno 2006). Se näkyy erityisesti työntekijöiden kuvauksissa siitä, kuinka heidän tulee kehittää itseään ja persoonallisia ominaisuuksiaan jatkuvasti myös vapaa-ajalla, jotta he kykenisivät pitämään yllä työkompetenssiaan sekä etenemään urallaan. Toisaalta taas työn subjektivoituminen näkyy erityisesti tunteisiin liittyvissä problematisoinneissa. Haastateltavat kuvaavat, kuinka he joutuvat työstämään, problematisoimaan ja hal- 
litsemaan sisäisyyttään ja kokemuksiaan - erityisesti epäoikeudenmukaisuuteen liittyviä tunteita - työyhteisön ongelmatilanteissa.

Tunteet ovat työssä tärkeitä, mutta eivät mitkä tahansa tunteet. Tunteet eivät aineiston perusteella näytä tuovan työyhteisöön yhteisöllisyyttä ja jakamisen kokemuksia, vaan juuri tunteiden hallinnan vaatimuksen myötä ihmiset ajautuvat erilleen. Kuten muissakin tutkimuksissa (Julkunen ym. 2009; Rikala 2013) on havaittu, työelämän ulossulkevat käytännöt, valtasuhteet ja yksilöön sisäistynyt luottamusvaje ovat osa työntekijöiden kokemusta työelämästä. Lisäarvon tuottamisen ohella tunteet myös kätkevät yhteisölle vaikeita kysymyksiä yksilöön.

Puutteen, syvän pettymyksen ja jopa depression kokemukset näkyvätkin aineistossa.Ihmiset kuvaavat olevansa erillään, sekä ikään kuin osia itsestään. Se, mitä haastateltavat eivät juuri kysy, on mitä työntekijät voisivat tarvita organisaatiolta. Kysymys asettuu ainoastaan toisin päin: mitä organisaatio näyttää haluavan työntekijältä ja onnistutaanko nämä normit täyttämään?

Kyse on siis jonkinlaisesta vastavuoroisuuden, yhteisten ratkaisujen, toivon ja sitä kautta toimintamahdollisuuksien puuttumisesta. Ihminen usein tuntee ristiriidat ennen kuin tietää ja ymmärtää niitä (Armstrong 2005). Aineistosta erottuvat pettymyksen, epätoivon ja depression kokemukset voidaan tulkita johtuvan vaikuttamismahdollisuuksien puuttumisesta organisaatiossa. Ne ilmentävät eräänlaista funktionaalista patologiaa (Ehrenberg 2009), joka voisi auttaa määrittelemään yksilön rajoja suhteessa organisaatioon.

Henkilökohtaista toivoa ylläpitäksseen työntekijät näyttävät myös identifioituvan johtajiin, mikä ei kuitenkaan tarkoita, että työntekijöiden ja johtajien välillä olisi varsinaista keskinäistä ymmärrystä asioiden tilasta. Pikemminkin kyse on heikosti tiedostetusta yrityksestä ratkaista yhteisötasolla syntynyt turvattomuus. Työntekijä sijoittaa toivoa ylläpitävät hyvät ominaisuudet johtajistoon niin voimallisesti, ettei niitä jää itseen. Bion (1979) pitää tällaista ryhmäkäyttäytymistä tapana reagoida turvattomuuden tunteeseen. Tämä selittää osaltaan puutteen, synkkyyden ja depression kokemukset työntekijöiden kertomuksissa.
Näyttää siltä, että keskijohto ja työntekijät jakavat tilanteessa lähinnä emotionaalisen kokemuksen, jota ei kuitenkaan osata sanallistaa. Kun tälle emotionaaliselle maailmalle ei ole käsitteitä eikä sen luonnetta ymmärretä, jäävät hyvää tarkoittavat ratkaisuyritykset - kuten työpaikkapsykologin palvelujen tarjoaminen työyhteisön kriisitilanteissa - puolitiehen. Pahimmillaan ne voivat kääntyä jopa itseään vastaan, vahvistamaan rakenteita, joita olisi tarkoituksenmukaisempaa kyseenalaistaa.

Muuttunut työ ja sen organisoinnin tavat näyttäytyvät työntekijöiden kokemuksissa mahdottomana yrityksenä olla vaatimusten mukainen. Yliopisto on uudistusten myötä päätynyt tilanteeseen, jossa sen toiminnalla odotetaan olevan esimerkiksi suoria vaikutuksia kansalliseen kilpailukykyyn. Tämä tuottaa eräänlaista "fantasiapuhetta”, toiveita siitä, miten asioiden on tarkoitus järjestyä. Vastuu näiden toiveiden toteutumisesta näyttäisi entistä enemmän siirtyneen yrittäjämäiselle työntekijälle. Vaatimukset ovat sisäistyneet työntekijän yksityisiksi ongelmiksi, joihin hän reagoi omalla sisäisellä, emotionaalisella logiikallaan. Alun perin luonteeltaan laajemmat ongelmat ovat näin sijoittuneet yksilöihin ja samalla muuttaneet luonnettaan.

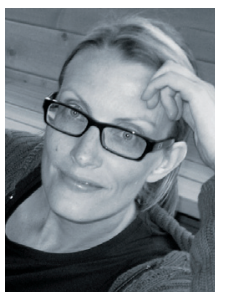

Tiina Nikkola

KT, FM tutkijatohtori Opettajankoulutuslaitos Jyväskylän yliopisto

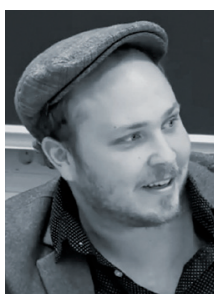

Esko Harni

YTM, KM väitöskirjatutkija Yhteiskuntatieteiden ja filosofian laitos Jyväskylän yliopisto 


\section{LÄHTEET}

Alhanen, K. (2007). Käytännöt ja ajattelu Michel Foucault'n filosofiassa. Helsinki: Gaudeamus.

Armstrong, D. (2005). Organization in the Mind. Psychoanalysis, Group Relations, and Organizational Consultancy. London: Karnac.

Bion, W. R. (1979). Kokemuksia ryhmistä. Ryhmädynamiikka psykoanalyysin näkökulmasta. Espoo: Weilin+Göös.

Dardot, P. \& Laval, C. (2014). The New Way of the World: On Neoliberal Society. New York: Verso Books.

Ehrenberg, A. (2009). The Weariness of the Self. Diagnosing the history of depression in the contemporary age. Montreal: McGill Queen's University Press.

Eskola, J. \& Suoranta, J. (1998). Johdatus laadulliseen tutkimukseen. Tampere: Vastapaino.

Foucault, M. (1982). The Subject and Power. Critical Inquiry 8(4), 777-795.

Foucault, M. (1998). Seksuaalisuuden historia. Tampere: Gaudeamus.

Hardt, M. (1991). Affective labour. http://www.english.ufl. edu/mrg/readings/Affective\%20Labor.pdf (tarkistettu 17.11.2015)

Hardt, M. \& Negri, A. (2005). Imperiumi. Helsinki: WSOY.

Holvas, J. \& Vähämäki, J. (2005). Odotustila. Pamfletti uudesta työstä. Helsinki: Teos.

Jakonen, M. (2014). Uusi työ ja prekarisaatio: Työn muutosten vaikutukset suomalaiseen hyvinvointivaltioon ja poliittiseen järjestäytymiseen. Tiede ja Edistys 39(4), 287-320.

Jakonen, M., Peltokoski, J. \& Virtanen, A. (toim.) (2006). Uuden työn sanakirja. Helsinki: Tutkijaliitto.

Jokinen, E. (2010). Affektiivinen työ ja sukupuoli. Kulttuurintutkimus 27(2), 44-49.

Jokinen, E. \& Venäläinen, J. (toim.) (2015). Prekarisaatio ja affekti. Jyväskylä: Nykykulttuurin tutkimuskeskus.

Julkunen, R. (2008). Uuden työn paradoksit. Tampere: Vastapaino.
Julkunen, R., Kaskisaari, M., Rikala, S. \& Virkki, T. (2009). Työelämän vanhat, vihaiset ja väsyneet. Valta ja haavoittuvuus työelämän luottamusrakenteissa. Jyväskylän yliopisto. https://www.tsr.fi/tsarchive/ files/TietokantaTutkittu/2004/104127Loppuraportti. pdf (tarkistettu 17.11.2015)

Mäkinen, K. (2012). Becoming Valuable Selves. SelfPromotion, Gender and Individuality in Late Capitalism. Tampere: Tampere University Press.

Mäkinen, K. (2013). Yksilöllinen potentiaali ja sukupuoli työelämävalmennuksessa. Sosiologia 50(2), 152-168.

Onnismaa, J. (2007). Työelämän kaksoissidokset ja niiden vastamyrkyt. Aikuiskasvatus 27(2), 103-113.

Puhakka, I. \& Rautopuro, J. (2012). Yliopistotyöstressin muutokset. Teoksessa Volanen, M. V. (toim.) Toiseksi paras? Tieteentekijät ja uusi yliopisto. Helsinki: Tieteentekijöiden liitto, 28-43.

Raunig, G. (2013). Factories of Knowledge, Industries of Creativity. New York: Semiotext(e) / Intervention Series.

Rikala, S. (2013). Työssä uupuvat naiset ja masennus. Tampere University Press.

Rose, N. (1989). Governing the Soul: The Shaping of the Private Self. London: Free Association Books.

Virno, P. (2006). Väen kielioppi. Helsinki: Tutkijaliitto.

Virtanen, A. (2006). Biopoliittisen talouden kritiikki. Helsinki: Tutkijaliitto.

Vähämäki, J. (2003). Kuhnurien kerho. Helsinki: Tutkijaliitto.

Vähämäki, J. (2015). Sielujen muovaamisen uusi ympäristö. Teoksessa Harni, E. (toim.) Kontrollikoulu: näkökulmia koulutukselliseen hallintaan ja toisin oppimiseen. Jyväskylä: Kampus Kustannus, 37-62.

Ylijoki, O.-H. (1991). Akateemiset heimokulttuurit ja noviisien sosialisaatio. Tampere: Vastapaino. 